Vegetalika. 2018. 7(4): 58-73

\title{
Pengaruh Lama Penyinaran Tambahan Krisan (Dendranthema sp.) Varietas Bakardi Putih dan Lolipop Ungu terhadap Pertumbuhan dan Hasil
}

\section{Growth and Yield Chrysanthemum (Dendranthema sp.) Bakardi Putih and Lolipop Ungu Under Additional Light}

\author{
Sylvatera Ayu Puspitasari, Didik Indradewa*) \\ Departemen Budidaya Pertanian, Fakultas Pertanian, Universitas Gadjah Mada \\ *) Penulis untuk koresponden Email: didikindradewa54@yahoo.com
}

\begin{abstract}
Chrysanthemum is a short day plant. If the plant gets long night over 12 hours as occurred in tropical area then the vegetative phase will terminated and plant start to flower. To maintain the vegetative phase, Chrysanthemum need additional light at night. A research was conducted to study the influence of the additional light at different plant ages to the growth, yield and quality of different varieties of Chrysanthemum and to find out the optimal length of additional light to harvest for different varieties. A research was conducted from August 2017 until March 2018 in greenhouse Asosiasi Tanaman Hias Bunga dan Daun Potong (ASTHABUNDA) Jalan Kaliurang km 21, Panggeran, Hargoninangun, Pakem, Sleman, DIY. The study used a factorial design $2 \times 5$, arranged in Randomized Complete Block design with three blocks as replications. The first factor was additional light with 5 levels $i$. e : 0 day (without additional light), 10 days, 20 days, 30 days and 40 days. The second factor was 2 varieties : Bakardi Putih and Lolipop Ungu. Result of the experiment showed that additional light 20 days on Bakardi Putih and 30 days on Lolipop Ungu that have met the grade A SNI. Additional light until 40 days could increase growth, yield and quality of Bakardi Putih better than Lolipop Ungu. An additional light 20 days on Bakardi Putih and Lolipop Ungu 30 days haven't been able to harvest in the same age. In 20 days, harvest age of Bakardi Putih was 86 days and 30 days Lolipop Ungu 106 days
\end{abstract}

Key words : additional light, Bakardi Putih, Chrysanthemum, Lolipop Ungu

\section{INTISARI}

Krisan merupakan tanaman hari pendek. Jika tanaman ini mendapatkan panjang malam lebih dari 12 jam dalam sehari maka fase vegetatif (pertambahan tinggi) tidak berlangsung lama. Untuk mempertahankan fase vegetatif tanaman krisan maka perlu dilakukan penambahan lama penyinaran di malam hari. Penelitian ini bertujuan untuk mempelajari 
Sylvatera Ayu Puspita et al., / Vegetalika. 2018. 7(4): 58-73

pengaruh lama penyinaran terhadap pertumbuhan, hasil dan kualitas varietas krisan yang berbeda serta mempelajari lama penyinaran tambahan optimal untuk menyerempakkan umur panen varietas krisan yang berbeda. Penelitian ini akan dilaksanakan pada bulan Agustus 2017 hingga Maret 2018 bertempat di lahan pertanaman krisan dan rumah plastik milik Asosiasi Tanaman Hias Bunga dan Daun Potong (ASTHABUNDA) Jalan Kaliurang km 21, Panggeran, Hargoninangun, Pakem, Sleman, DIY. Penelitian menggunakan Rancangan Faktorial $2 \times 5$, tata letak Rancangan Acak Kelompok Lengkap dengan tiga blok sebagai ulangan. Faktor 1 adalah lama penyinaran tambahan dengan 5 aras yaitu 0 hari (tanpa penyinaran), 10 hari, 20 hari, 30 hari dan 40 hari. Faktor 2 adalah varietas yaitu Bakardi Putih dan Lolipop Ungu. Kombinasi perlakuan berjumlah 10 perlakuan dengan masing masing kombinasi 3 sampel tanaman dengan 3 ulangan. Hasil penelitian menunjukkan penyinaran tambahan 20 hari pada varietas Bakardi Putih dan 30 hari Lolipop Ungu menghasilkan bunga krisan yang telah memenuhi grade A SNI. Peningkatan lama penyinaran tambahan sampai dengan 40 ari dapat meningkatkan pertumbuhan, hasil dan kualitas varietas Bakardi Putih lebih baik dibandingkan varietas Lolipop Ungu. Penyinaran tambahan 20 hari pada varietas Bakardi Putih dan 30 hari varietas Lolipop Ungu belum dapat menyerempakkan umur panen kedua varietas. Pada penyinaran 20 hari, umur panen varietas Bakardi Putih 86 hari dan 30 hari varietas Lolipop Ungu 106 hari.

Kata kunci : Bakardi Putih, krisan, lama penyinaran, Lolipop Ungu

\section{PENDAHULUAN}

Krisan mempunyai daya tarik keindahan yang dapat memikat setiap orang yang melihatnya. Krisan kaya akan warna dan tahan lama. Yogyakarta merupakan kota wisata sehingga permintaan bunga krisan potong sangat tinggi yang digunakan untuk hiasan hotel, dekorasi dan upacara-upacara. Akan tetapi permintaan bunga krisan di Yogyakarta tidak sebanding dengan produksi yang dihasilkan. Kebutuhan akan bunga krisan di Yogyakarta baru terpenuhi sekitar $20 \%, 80 \%$ nya masih dari kota lain. Sejak tahun 2000 hingga 2013, luas panen krisan di Indonesia meningkat dari 1.160.170 menjadi 9.080.709 $\mathrm{m}^{2}$ atau tumbuh rata-rata $25,84 \%$ per tahun. Penawaran krisan Indonesia merupakan representasi dari produksi krisan di Indonesia (Ekanantari, 2014). Menurut Vina (2016), krisan mempunyai banyak manfaat diantaranya sebagai tumbuhan obat tradisional dan penghasil racun serangga. Bunga krisan dapat diolah menjadi minuman seperti teh sedangkan daun krisan dapat diiolah menjadi makanan seperti keripik. Penelitian yang dilakukan oleh Pin et al. (1999) pada Chrysanthemum morifolium, menunjukkan bahwa ekstrak bunga krisan jenis tersebut memiliki kandungan antioksidan yang cukup tinggi. Penelitian Zhu et al. (2005) menunjukkan bahwa minyak esensial yang terdapat pada 
Sylvatera Ayu Puspita et al., / Vegetalika. 2018. 7(4): 58-73

bunga Chrysanthemum indicum memiliki kemampuan menghambat pertumbuhan 15 macam mikroorganisme.

Cahaya merupakan faktor lingkungan yang sangat mempengaruhi kenampakan fenotif tanaman (Han et al., 2017). Krisan merupakan tanaman hari pendek. Jika tanaman ini mendapatkan panjang malam lebih dari 12 jam sehari maka fase vegetatif (pertambahan tinggi) tidak berlangsung lama dan menyebabkan tinggi bunga krisan pada waktu panen hanya 40 -an $\mathrm{cm}$. Untuk mempertahankan fase vegetatif tanaman krisan maka perlu dilakukan penambahan lama penyinaran di malam hari dengan demikian akan diperoleh bunga krisan dengan kualitas yang diharapkan yaitu tinggi $>70 \mathrm{~cm}$. Pengaruh lama penyinaran yang berbeda mempengaruhi morfologi tanaman krisan.

Pada budidaya tanaman krisan potong tipe spray dilakukan tambahan penyinaran saat fase vegetatif untuk mempertahankan fase vegetatif dan menghambat fase generatif (Park et al., 2013). Krisan varietas Bakardi putih mempunyai umur panen sekitar 90 hari seperti varietas krisan pada umumnya sedangkan varietas Lolipop ungu mempunyai umur panen yang lebih lama yaitu lebih dari 100 hari. Perbedaan waktu panen yang dibutuhkan oleh kedua varietas krisan potong menyebabkan kedua varietas tersebut tidak dapat dipanen secara serentak apabila ditanam secara bersamaan padahal konsumen menginginkan krisan potong dengan berbagai warna sehingga saat Lolipop Ungu panen hanya terdapat satu warna.

Usahatani tanaman krisan yang baik akan menghasilkan bunga potong krisan yang bermutu tinggi dan tentu meningkatkan pendapatan karena harga jual bunga potong krisan dipengaruhi oleh kualitas bunga yang dihasilkan petani. Permintaan bunga krisan potong yang meningkat menciptakan peluang bagi petani produsen dan pengusaha bunga krisan untuk meningkatkan kualitas, kuantitas dan kontinuitas produksi bunga krisan yang sesuai dengan permintaan pasar. Masalah yang dihadapi dalam pengembangan budidaya tanaman untuk produksi bunga krisan hingga saat ini yaitu mengenai kualitas bunga dan lamanya waktu yang dibutuhkan untuk panen. Menurut Park et al. (2016), memanipulasi fotoperiode dengan pengaturan penyinaran tambahan dapat mengurangi biaya produksi dengan mengurangi waktu produksi dan meningkatkan kualitas keseluruhan tanaman. Penelitian ini bertujuan untuk mempelajari pengaruh lama penyinaran tambahan terhadap pertumbuhan, hasil dan kualitas varietas krisan yang 
Sylvatera Ayu Puspita et al., / Vegetalika. 2018. 7(4): 58-73

berbeda serta mempelajari lama penyinaran tambahan optimal untuk menyerempakkan umur panen varietas krisan yang berbeda.

\section{BAHAN DAN METODE PENELITIAN}

Penelitian ini dilaksanakan pada bulan Agustus 2017 hingga Maret 2018 bertempat di lahan pertanaman krisan dan rumah plastik milik Asosiasi Tanaman Hias Bunga dan Daun Potong (ASTHABUNDA) Jalan Kaliurang km 21, Panggeran, Hargoninangun, Pakem, Sleman, DIY, terletak pada ketinggian 650 mdpl. Alat yang digunakan dalam penelitian ini meliputi alat-alat pertanian, alat tulis, jaring penegak, mulsa perak hitam, lampu TL (merk philips, 23 watt), jangka sorong digital, kamera digital, dan timer. Bahan yang digunakan adalah bibit tanaman krisan varietas Bakardi Putih dan Lolipop Ungu yang tersedia di lapangan, pupuk kandang, pupuk NPK, fungisida (Antracol, Bion m, Nativo, dan Detaine), akarisida (Samidte), dan insektisida (Confidor, Topdor, Proclim dan Abamectin). Penelitian menggunakan Rancangan Faktorial 2 × 5, tata letak Rancangan Acak Kelompok Lengkap dengan tiga blok sebagai ulangan. Faktor 1 adalah lama penyinaran tambahan dengan 5 aras yaitu 0 hari (tanpa penyinaran), 10 hari, 20 hari, 30 hari dan 40 hari. Lama penyinaran tambahan diberikan 4 jam sehari pada pukul 19.00-23.00 WIB. Intensitas cahaya pada lampu adalah 88 lux. Faktor 2 adalah varietas yaitu Bakardi Putih dan Lolipop Ungu. Kombinasi perlakuan berjumlah 10 perlakuan dengan masing masing kombinasi 3 sampel tanaman dengan 3 ulangan. Variabel penelitian yang diamati adalah jumlah daun, luas daun, umur muncul knop, umur panen, tinggi tanaman, jumlah bunga, diameter batang, diameter bunga dan lama kesegaran.

\section{HASIL DAN PEMBAHASAN}

Krisan merupakan tanaman hari pendek dengan periode kritis 16 jam perhari sedangkan panjang hari Indonesia sekitar 12 jam perhari. Untuk mendapatkan krisan yang sesuai dengan konsumen harus dilakukan teknik budidaya yang baik untuk mencapai hasil yang optimal. Menurut Pusat Penelitian dan Pengembangan Hortikultura (2006) perbaikan teknik budidaya dilakukan dengan menerapkan teknologi budidaya anjuran spesifik lokasi dan komponen-komponen lain secara terpadu.

Lama penyinaran mempengaruhi pertumbuhan dan hasil dari tanaman krisan. Tanaman krisan tanpa penyinaran tambahan menghasilkan kenampakan tanaman yang 
Sylvatera Ayu Puspita et al., / Vegetalika. 2018. 7(4): 58-73

lebih pendek, kecil, dan cepat berbunga sedangkan krisan yang mendapatkan lama penyinaran tambahan memberikan hasil tanaman yang lebih tinggi, besar dan berbunga lama. Tanaman krisan apabila diberikan lama penyinaran tambahan maka akan menghambat fase generatif dari tanaman krisan (Park et al., 2013) dan memperpanjang fase vegetatif untuk memberikan hasil tanaman krisan yang optimal. Tanaman hari pendek apabila berada pada kondisi panjang hari yang kurang dari periode kritisnya maka akan langsung memasuki fase generatif namun pertumbuhannya belum optimal dan belum memenuhi kriteria sebagai bunga potong. Secara fisiologis, cahaya mempunyai pengaruh langsung melalui proses fotosintesis sedangkan pengaruh tidak langsung melalui pertumbuhan dan perkembangan tanaman. Proses perkembangan yang dikendalikan oleh cahaya mempengaruhi morfologi tanaman serta induksi pembungaan (Widiastuti dkk, 2004). Antar organ tanaman berkaitan sehingga memberikan kenampakan hasil pada tanaman.

Cahaya pada lama penyinaran tambahan diserap oleh fitokrom yang terdapat di daun. Fitokrom dimungkinkan untuk menyelaraskan waktu dengan lingkungan dengan memberitahukan pada tanaman kapan matahari terbit dan terbenam. Jika kebutuhan fotoperiode telah terpenuhi maka akan menyebabkan daun mengirimkan stimulus pembungaan ke tunas. Stimulus yang dimaksud adalah florigen yang merupakan hormon untuk menginduksi terbentuknya bunga (Yoginugraha dkk, 2017). Fotoperiode mengatur pertumbuhan dan pembungaan pada tanaman (Kim et al., 2011). Pembungaan diatur oleh panjang malam gelap (Runkle et al., 2012).

Warnita, et al. (2015) menuliskan daun merupakan organ untuk melakukan fotosintesis yang dapat menghasilkan karbohidrat yang digunakan untuk pertumbuhan dan perkembangan, pertambahan jumlah daun akan menyebabkan banyaknya cahaya, $\mathrm{CO}_{2}$ dan air yang masuk melalui stomata daun sehingga dapat meningkatkan fotosintesis, dengan meningkatnya fotosintesis akan meningkatkan karbohidrat yang banyak sehingga dapat digunakan untuk meningkatkan pertumbuhan tanaman secara keseluruhan. 
Sylvatera Ayu Puspita et al., / Vegetalika. 2018. 7(4): 58-73

Tabel 1. Jumlah daun krisan

\begin{tabular}{|c|c|c|c|}
\hline \multirow{2}{*}{$\begin{array}{l}\text { Lama Penyinaran Tambahan } \\
\text { (hari) }\end{array}$} & \multicolumn{2}{|c|}{ Varietas } & \multirow{2}{*}{ Rerata } \\
\hline & Bakardi & Lolipop & \\
\hline 0 (tanpa penyinaran) & $34,22 \mathrm{~d}$ & $33,22 \mathrm{~d}$ & 33,72 \\
\hline 10 & $36,11 \mathrm{~d}$ & $28,33 d$ & 32,22 \\
\hline 20 & $41,05 \mathrm{~cd}$ & $53,16 \mathrm{bc}$ & 47,10 \\
\hline 30 & $59,61 a b$ & $67,00 \mathrm{ab}$ & 63,30 \\
\hline 40 & 73,89 a & $66,55 \mathrm{ab}$ & 70,22 \\
\hline Rerata & 48,97 & 49,65 & \\
\hline $\mathrm{KK}$ & \multicolumn{2}{|c|}{11,42} & + \\
\hline
\end{tabular}

Keterangan: Angka diikuti huruf yang sama menunjukan tidak ada beda nyata berdasarkan uji lanjut Tukey $5 \%$. Tanda (+) menunjukan adanya interaksi antara varietas dan lama penyinaran tambahan.

Ada interaksi antara varietas dan lama penyinaran tambahan pada jumlah daun. Varietas Bakardi yang diberikan lama penyinaran sampai 20 hari menghasilkan jumlah daun yang tidak berbeda nyata, sedangkan varietas Lolipop hingga 10 hari. Jumlah daun akan bertambah secara nyata bila diberikan penyinaran tambahan untuk varietas Bakardi selama lebih dari 30 hari sedangkan varietas Lolipop cukup lebih dari 20 hari. Jumlah daun varietas Bakardi lebih sedikit dibandingkan varietas Lolipop.

Salah satu indikator yang dapat diamati dari hasil fotosintesis yaitu pertambahan jumlah daun. Pengamatan jumlah daun dapat menganalisis pertumbuhan pada fase vegetatif serta menunjukkan pengaruh waktu dan lama penyinaran tambahan terhadap pertumbuhan tanaman. Menurut Arista (2016), semakin banyak jumlah daun yang dihasilkan maka dapat mengoptimalkan fotosintesis. Banyaknya daun dapat memaksimalkan penyerapan cahaya sehingga fotosintat dari hasil fotositesis dapat ditranslokasikan ke seluruh organ tanaman. Berdasarkan Tabel 1, secara umum jumlah daun meningkat dengan penambahan lama penyinaran yang semakin lama sehingga dapat memaksimalkan penyerapan foton dari cahaya matahari. Akan tetapi pada varietas Lolipop dengan lama penyinaran tambahan 30 hari menghasilkan jumlah daun yang lebih banyak dibandingkan dengan lama penyinaran tambahan 40 hari. Hal ini dapat dikarenakan krisan dengan penyinaran tambahan 40 hari mempunyai daun yang sedikit namun lebar karena dibuktikan dengan luas daun yang paling luas. 
Sylvatera Ayu Puspita et al., / Vegetalika. 2018. 7(4): 58-73

Tabel 2. Luas daun krisan $\left(\mathrm{dm}^{2}\right)$

\begin{tabular}{|c|c|c|c|}
\hline \multirow{2}{*}{ Perlakuan } & \multicolumn{3}{|c|}{ Luas Daun } \\
\hline & 20 hari & 50 hari & Panen \\
\hline \multicolumn{4}{|l|}{ Varietas } \\
\hline Bakardi & $0,70 \mathrm{a}$ & $3,20 \mathrm{~b}$ & $4,20 \mathrm{~b}$ \\
\hline Lolipop & $0,70 \mathrm{a}$ & $3,94 \mathrm{a}$ & $5,28 \mathrm{a}$ \\
\hline \multicolumn{4}{|c|}{$\begin{array}{l}\text { Lama penyinaran tambahan } \\
\text { (hari) }\end{array}$} \\
\hline 0 (tanpa penyinaran) & $0,60 \mathrm{a}$ & $2,61 \mathrm{c}$ & $1,95 d$ \\
\hline 10 & $0,61 \mathrm{a}$ & $2,61 \mathrm{c}$ & $2,79 \mathrm{~cd}$ \\
\hline 20 & $0,65 \mathrm{a}$ & $3,40 \mathrm{~b}$ & $4,22 \mathrm{c}$ \\
\hline 30 & $0,83 a$ & $4,42 \mathrm{a}$ & $6,50 \mathrm{~b}$ \\
\hline 40 & $0,83 a$ & $4,81 \mathrm{a}$ & $8,24 \mathrm{a}$ \\
\hline Rerata & 0,70 & 3,57 & 4,74 \\
\hline $\mathrm{KK}$ & 19,10 & 12,26 & 20,34 \\
\hline Interaksi & - & - & - \\
\hline
\end{tabular}

Tidak ada interaksi pengaruh lama penyinaran tambahan dan varietas pada luas daun di umur 20 hari, 50 hari serta panen. Tidak terdapat perbedaan luas daun varietas Bakardi Putih dan Lolipop pada umur 20 hari sedangkan pada umur 50 hari dan saat panen didapatkan perbedaan nyata (Tabel 2). Semakin bertambahnya umur, luas daun semakin lebar dan menunjukkan bahwa varietas Bakardi mempunyai luas daun yang lebih sempit dibanding varietas Lolipop. Pada umur 20 hari, perlakuan lama penyinaran tambahan pada luas daun tidak berbeda nyata. Luas daun pada umur 50 hari tidak berbeda nyata pada lama penyinaran tambahan hingga 10 hari. Pada saat panen, luas daun berbeda nyata pada lama penyinaran tambahan 30 hari.

Walton et al. (2006) menyatakan bahwa luas area daun dipengaruhi oleh panjang hari. Berdasarkan Tabel 2. dapat dilihat bahwa semakin lama penyinaran tambahan yang diberikan maka akan menghasilkan luas daun yang lebih luas. Lama penyinaran tambahan 40 hari menghasilkan luas daun terluas. Sedangkan tanpa penyinaran tambahan menghasilkan luas daun yang sempit.

Tabel 3. Umur muncul knop krisan (hari) 
Sylvatera Ayu Puspita et al., / Vegetalika. 2018. 7(4): 58-73

\begin{tabular}{lccc}
\hline \multirow{2}{*}{$\begin{array}{l}\text { Lama Penyinaran Tambahan } \\
\text { (hari) }\end{array}$} & \multicolumn{2}{c}{ Varietas } & \multirow{2}{*}{ Rerata } \\
\cline { 2 - 3 } & Bakardi & Lolipop & \\
\hline 0 (tanpa penyinaran) & $23,05 \mathrm{~h}$ & $35,77 \mathrm{~g}$ & 29,41 \\
10 & $36,89 \mathrm{~g}$ & $42,11 \mathrm{f}$ & 39,50 \\
20 & $45,38 \mathrm{e}$ & $49,50 \mathrm{~d}$ & 47,44 \\
30 & $51,83 \mathrm{~d}$ & $54,77 \mathrm{c}$ & 53,30 \\
40 & $58,50 \mathrm{~b}$ & $62,22 \mathrm{a}$ & 60,36 \\
\hline Rerata & 43,13 & 48,87 & + \\
\hline KK & \multicolumn{3}{|c}{1,79} \\
\hline
\end{tabular}

Keterangan: Angka diikuti huruf yang sama menunjukan tidak ada beda nyata berdasarkan uji lanjut Tukey $5 \%$. Tanda (+) menunjukan adanya interaksi antara varietas dan lama penyinaran tambahan.

Knop merupakan organ tanaman yang nantinya akan membentuk bunga. Tabel 3 menunjukkan adanya interaksi antara varietas dengan lama penyinaran tambahan pada umur muncul knop. Semakin lama penyinaran tambahan yang diberikan pada krisan mengakibatkan umur muncul knop lebih lama. Hal tersebut dapat terlihat dari lama penyinaran tambahan 40 hari memberikan hasil umur muncul knop yang paling lama. Umur muncul knop varietas Bakardi lebih cepat dibandingkan varietas Lolipop. Secara umum, umur muncul knop pada kedua varietas dengan lama penyinaran tambahan yang berbeda memberikan hasil yang berbeda nyata. Menurut Park et al. (2013), tanaman Zinnia yang diganggu malamnya dengan penambahan cahaya menghasilkan umur muncul bunga yang lebih lama dibandingan dengan perlakuan hari pendek. Umur muncul knop menunjukkan jumlah hari yang dibutuhkan untuk menginduksi bunga krisan. Varietas Bakardi terinduksi terlebih dahulu dibandingkan varietas Lolipop. Hal ini dimungkinkan karena adanya perbedaan genetik pada kedua varietas tersebut sehingga mempunyai respon terinduksi pembungaan yang berbeda.

Tabel 4. Umur panen krisan (hari)

\begin{tabular}{lccc}
\hline Lama Penyinaran & \multicolumn{2}{c}{ Varietas } & \multirow{2}{*}{ Rerata } \\
\cline { 2 - 3 } Tambahan (hari) & Bakardi & Lolipop & 84,17 \\
\hline 0 (tanpa penyinaran) & 76,56 & 91,78 & 87,39 \\
10 & 80,44 & 94,33 & 94,36 \\
20 & 86,72 & 102,00 & 102,17 \\
30 & 97,67 & 106,67 & 108,00 \\
40 & 102,06 & 113,94 & \\
\hline Rerata & 88,69 & 101,74 & \\
\hline
\end{tabular}

Berdasarkan Tabel 4 didapatkan varietas Bakardi dan Lolipop yang diberikan lama penyinaran tambahan yang sama tidak dapat mempunyai umur panen pada waktu yang 
Sylvatera Ayu Puspita et al., / Vegetalika. 2018. 7(4): 58-73

bersamaan. Varietas Bakardi mempunyai umur panen yang lebih cepat dibandingkan varietas Lolipop. Selisih umur panen antara kedua varietas mencapai 13 hari. Semakin lama penyinaran tambahan dilakukan maka umur panen yang lebih lama. Tanpa penambahan penyinaran menghasilkan umur panen yang lebih cepat sehingga tanaman langsung memasuki fase generatif karena mendapatkan panjang hari kurang dari periode kritisnya.

Tabel 5. Tinggi tanaman krisan (cm)

\begin{tabular}{|c|c|c|c|}
\hline \multirow{2}{*}{$\begin{array}{l}\text { Lama Penyinaran Tambahan } \\
\text { (hari) }\end{array}$} & \multicolumn{2}{|c|}{ Varietas } & \multirow{2}{*}{ Rerate } \\
\hline & Bakardi & Lolipop & \\
\hline 0 (tanpa penyinaran) & $43,80 \mathrm{f}$ & $43,61 \mathrm{f}$ & 43,70 \\
\hline 10 & $54,08 \mathrm{e}$ & 50,35 ef & 52,21 \\
\hline 20 & $70,61 \mathrm{~cd}$ & $63,97 d$ & 67,29 \\
\hline 30 & $89,44 \mathrm{~b}$ & $75,99 \mathrm{c}$ & 82,71 \\
\hline 40 & $102,64 \mathrm{a}$ & 86,94 b & 94,79 \\
\hline Rerata & 72,11 & 64,17 & \\
\hline KK & \multicolumn{2}{|c|}{1,79} & + \\
\hline
\end{tabular}

Keterangan: Angka diikuti huruf yang sama menunjukan tidak ada beda nyata berdasarkan uji lanjut Tukey $5 \%$. Tanda $(+)$ menunjukan adanya interaksi antara varietas dan lama penyinaran tambahan.

Adanya interaksi antara varietas dengan lama penyinaran tambahan pada tinggi tanaman. Varietas Bakardi dengan lama penyinaran tambahan 40 hari menghasilkan tinggi tanaman tertinggi. Semakin lama penyinaran tambahan diberikan, maka krisan akan tetap pada fase vegetatif. Pada tabel 5 didapatkan tinggi tanaman varietas Bakardi lebih tinggi dibandingkan Lolipop. Untuk mencapai tinggi $70 \mathrm{~cm}$, varietas Bakardi perlu diberikan lama penyinaran tambahan selama 20 hari sedangkan untuk varietas Lolipop diperlukan 30 hari. Jika krisan mendapatkan penyinaran kurang dari 12 jam maka fase vegetatif (pertambahan tinggi) tidak berlangsung lama dan menyebabkan tinggi bunga krisan pada waktu panen hanya sekitar $40 \mathrm{~cm}$. Hasil penelitian ini mendukung penelitian sebelumnya yang dilakukan oleh Walton et al. (2006) yang menyatakan bahwa tinggi tanaman hari pendek akan lebih tinggi ketika diberikan perlakuan hari panjang. Hal ini dimungkinkan karena proses fotosintesis ketika hari panjang berlangsung lebih lama, sehingga lebih banyak menghasilkan fotosintat yang digunakan untuk pertumbuhan vegetatif tanaman, diantaranya adalah tinggi tanaman. Menurut Chen et al. (2011), tanaman hari pendek seperti gandum yang mendapatkan sinar penuh optimal akan menghasilkan fotosintesis yang efisien 
Sylvatera Ayu Puspita et al., / Vegetalika. 2018. 7(4): 58-73

Tabel 6. Jumlah bunga krisan

\begin{tabular}{lccc}
\hline \multirow{2}{*}{$\begin{array}{l}\text { Lama Penyinaran Tambahan } \\
\text { (hari) }\end{array}$} & \multicolumn{2}{c}{ Varietas } & \multirow{2}{*}{ Rerata } \\
\cline { 2 - 3 } & Bakardi & Lolipop & \\
\hline 0 (tanpa penyinaran) & $4,16 \mathrm{c}$ & $3,77 \mathrm{c}$ & 3,96 \\
10 & $4,66 \mathrm{c}$ & $4,55 \mathrm{c}$ & 4,60 \\
20 & $5,00 \mathrm{c}$ & $5,89 \mathrm{bc}$ & 5,44 \\
30 & $9,61 \mathrm{~b}$ & $6,66 \mathrm{bc}$ & 8,13 \\
40 & $15,44 \mathrm{a}$ & $7,44 \mathrm{bc}$ & 11,4 \\
\hline Rerata & 7,77 & 5,66 & \\
\hline KK & \multicolumn{3}{c}{18,95} \\
\hline
\end{tabular}

Keterangan: Angka diikuti huruf yang sama menunjukan tidak ada beda nyata berdasarkan uji lanjut Tukey $5 \%$. Tanda (+) menunjukan adanya interaksi antara varietas dan lama penyinaran tambahan.

Tabel 6 menunjukkan adanya interaksi antara varietas dan lama penyinaran tambahan pada jumlah bunga. Jumlah bunga varietas Bakardi memberikan perbedaan nyata ketika mendapat lama penyinaran tambahan mulai 30 hari. Varietas Bakardi dengan lama penyinaran tambahan 40 hari menghasilkan jumlah bunga terbanyak. Varietas Lolipop dengan berbagai lama penyinaran tambahan tidak menghasilkan perbedaan nyata. Jumlah bunga yang banyak dapat mengindikasikan bahwa pertumbuhan tanaman krisan baik dalam mengoptimalkan peran cahaya. Menurut Sari (2010), semakin banyak jumlah kuntum bunga dalam setiap batangnya, maka secara tidak langsung batang semakin tinggi sehingga sering kali dikategorikan sebagai bunga yang berkualitas baik. Hal ini didukung oleh penelitian Noviawanti (2014) yaitu peningkatan lama penyinaran dapat meningkatkan jumlah bunga yang terbentuk. Pada fase gelap hasil fotosintat lebih difokuskan pada pembentukan bunga. Semakin lama fase gelap yang didapatkan oleh tanaman maka akan semakin banyak hasil fotosintat yang ditranslokasikan pada inisiasi pembungaan atau pembentukan bunga. Menurut Danalotos dan Archontoulis (2010), perbedaan antar varietas menghasilkan penampilan pertumbuhan yang berbeda, baik pada varietas Lolipop dan varietas Bakardi dikarenakan adanya perbedaan kecepatan pembelahan, perbanyakan, dan pembesaran sel. Kondisi tersebut menunjukkan adanya perbedaan faktor genetik yang dimiliki masing-masing varietas dan kemampuannya beradaptasi terhadap lingkungan. 
Sylvatera Ayu Puspita et al., / Vegetalika. 2018. 7(4): 58-73

Tabel 7. Diameter batang krisan $(\mathrm{mm})$ dan diameter bunga krisan $(\mathrm{cm})$

\begin{tabular}{lcc}
\hline Perlakuan & Diameter Batang & Diameter Bunga \\
\hline Varietas & $4,69 \mathrm{~b}$ & $5,40 \mathrm{a}$ \\
Bakardi & $6,03 \mathrm{a}$ & $4,95 \mathrm{~b}$ \\
Lolipop & & \\
\hline Lama penyinaran tambahan & & \\
(hari) & $4,46 \mathrm{~d}$ & $4,62 \mathrm{~b}$ \\
0 (tanpa penyinaran) & $5,00 \mathrm{~cd}$ & $5,12 \mathrm{ab}$ \\
10 & $5,38 \mathrm{bc}$ & $5,15 \mathrm{ab}$ \\
20 & $5,83 \mathrm{ab}$ & $5,31 \mathrm{a}$ \\
30 & $6,13 \mathrm{a}$ & $5,67 \mathrm{a}$ \\
40 & 5,36 & 5,17 \\
\hline Rerata & 7,80 & 6,95 \\
\hline KK & - & - \\
\hline Interaksi & & \\
\hline Keterangan: Angka diikuti huruf yang sama menunjukan tidak ada beda nyata berdasarkan uji \\
lanjut Tukey 5\%. Tanda (+) menunjukan adanya interaksi antara varietas dan lama penyinaran \\
tambahan.
\end{tabular}

Tidak ada interaksi antara pengaruh lama penyinaran tambahan terhadap diameter batang dan diameter bunga dua varietas krisan yang diuji. Varietas Bakardi menghasilkan diameter batang dan diameter bunga yang berbeda nyata dengan varietas Lolipop. Varietas Bakardi mempunyai diameter batang yang lebih kecil dibandingkan varietas Lolipop akan tetapi diameter bunga yang dihasilkan lebih besar. Diameter batang dan diameter bunga yang diberikan lama penyinaran tambahan yang berbeda cenderung tidak menghasilkan perbedaan nyata. Menurut Park et al. (2013), diameter bunga tidak berpengaruh nyata karena adanya lama penyinaran tambahan

Tabel 8. Lama kesegaran tanaman krisan (hari)

\begin{tabular}{llll}
\hline \multirow{2}{*}{$\begin{array}{l}\text { Lama Penyinaran Tambahan } \\
\text { (hari) }\end{array}$} & \multicolumn{2}{c}{ Varietas } & \multirow{2}{*}{ Rerata } \\
\cline { 2 - 3 } 0 (tanpa penyinaran) & $3,00 \mathrm{~d}$ & Lolipop & $3,00 \mathrm{~d}$ \\
10 & $4,00 \mathrm{c}$ & $4,00 \mathrm{c}$ & 4,00 \\
20 & $4,00 \mathrm{c}$ & $5,00 \mathrm{~b}$ & 4,50 \\
30 & $4,00 \mathrm{c}$ & $5,00 \mathrm{~b}$ & 4,50 \\
40 & $4,00 \mathrm{c}$ & $6,00 \mathrm{a}$ & 5,00 \\
\hline Rerata & 3,80 & 4,60 & \\
\cline { 1 - 3 } KK & & 0 & + \\
\hline
\end{tabular}

Keterangan: Angka diikuti huruf yang sama menunjukan tidak ada beda nyata berdasarkan uji lanjut Tukey $5 \%$. Tanda $(+)$ menunjukan adanya interaksi antara varietas dan lama penyinaran tambahan.

Tabel 8 menunjukkan adanya interaksi antara varietas dan lama penyinaran tambahan pada lama kesegaran. Lama kesegaran varietas Bakardi yang mendapat lama 
Sylvatera Ayu Puspita et al., / Vegetalika. 2018. 7(4): 58-73

penyinaran tambahan tidak berbeda nyata sedangkan varietas Lolipop berbeda nyata. Lama kesegaran varietas Bakardi lebih singkat dibandingkan varietas Lolipop. Lama kesegaran (vase life), menyangkut kemampuan bunga untuk dapat bertahan lama dengan tingkat kesegaran yang relatif tetap mendekati seperti halnya pada saat di panen. Seiring berjalannya waktu, bunga potong tidak selamanya selalu berada dalam kondisi SNI atau standar mutu pemasaran. Berdasarkan hasil penelitian, lama kesegaran bunga krisan tidak lebih dari 6 hari. Semakin lama penyinaran tambahan mengakibatkan lama kesegaran bunga krisan semakin lama dimungkinkan karena semakin lama penyinaran tambahan maka krisan lebih besar dan tinggi sehingga cadangan asimilat lebih banyak untuk bertahan hidup setelah proses pemanen. Menurut Ristiana (2016), diameter tangkai bunga merupakan salah satu indikator yang berpengaruh langsung dengan lama kesegaran bunga. Hal ini dikarenakan pada bagian batang terdapat jaringan angkut (floem) yang berfungsi untuk mentranslokasikan air, mineral dan hasil fotosintat pada seluruh bagian tubuh tanaman. Hal tersebut didukung dengan hasil penelitian yang menunjukkan diameter batang varietas Bakardi lebih kecil dibandingkan varietas Lolipop sehingga varietas Bakardi mempunyai lama kesegaran yang lebih cepat. Faktor lain dikemukakan Jones dan Hill (1993), bahwa kesegaran bunga potong yang singkat disebabkan oleh kekurangan nutrisi, kehilangan air dan terhambatnya penyerapan cairan dikarenakan xylem tersumbat oleh mikroorganisme.

Kualitas bunga krisan potong merupakan faktor utama penentu preferensi konsumen. Kualitas dan mutu bunga adalah faktor yang sangat mempengaruhi harga jual bunga krisan. Walaupun terdapat faktor lainnya seperti perbedaan selera dan trend. Koperasi ASTHABUNDA mengklasifikasikan kelas mutu krisan menjadi beberapa kelas berdasarkan Badan Standarisasi Nasional- BSN SNI 01-4478 tahun 1998. Kelas mutu krisan dibagi menjadi 4 yaitu kelas AA, A. B dan C. Koperasi ASTHABUNDA tidak menerapkan kelas $\mathrm{AA}$.

Berdasarkan hasil penelitian, didapatkan tinggi tanaman dengan lama penyinaran tambahan varietas Bakardi lebih dari 20 hari sudah dapat mencapai kelas A tetapi untuk lama penyinaran tambahan 10 hari dan tanpa penyinaran tambahan tidak memenuhi kriteria kelas mutu dan dapat di kategorikan kelas C yaitu asalan. Sedangkan varietas Lolipop dapat mencapai kelas A apabila mendapat lama penyinaran tambahan lebih dari 30 hari, lama penyinaran tambahan 20 hari masuk ke dalam kelas $B$. tanpa penyinaran 
Sylvatera Ayu Puspita et al., / Vegetalika. 2018. 7(4): 58-73

dan lama penyinaran tambahan 10 hari masuk ke dalam kelas $\mathrm{C}$. Diameter batang masuk dalam kelas A pada semua lama penyinaran tambahan yang diberikan.

Tanaman krisan yang dipanen merupakan tanaman krisan yang sesuai dengan kriteria panen salah satunya adalah bunga dalam keadaan setengah mekar (Sutanto, 2013). Apabila krisan baru dipanen ketika bunga telah mekar sempurna maka krisan tidak akan bertahan lama kesegarannya dan lebih mudah berubah warna saat penyimpanan. Berdasarkan hasil penelitian didapatkan diameter bunga lebih dari $4 \mathrm{~cm}$ sehingga sudah masuk ke dalam kelas A. Untuk krisan tipe spray, diameter bunga bukan merupakan kriteria utama karena yang lebih diutamakan jumlah bunga yang terbentuk sehingga untuk kemekaran $4 \mathrm{~cm}$ sudah dianggap cukup baik dan diterima konsumen. Diameter bunga yang dihasilkan kedua varietas sekitar $4-5 \mathrm{~cm}$. bunga krisan yang sudah mekar sempurna dapat mencapai 6-7 cm. Jumlah bunga setengah mekar dengan lama penyinaran tambahan 20 hari atau lebih pada kedua varietas menghasilkan krisan kelas A sedangkan untuk mecapai kelas $B$ dengan penambahan lama penyinaran 10 hari. Lama penyinaran tambahan 30 hari dan 40 hari cukup untuk mendapat kelas AA.

Secara keseluruhan, untuk mendapatkan hasil tanaman krisan dengan kelas mutu A maka diperlukan lama penyinaran tambahan untuk varietas Bakardi minimal 20 hari sedangkan varietas Lolipop minimal 30 hari. Akan tetapi, umur panen kedua verietas yaitu Bakardi dan Lolipop tidak dapat diserempakkan dengan perlakuan lama penyinaran yang berbeda tersebut. Berdasarkan Tabel 5 didapatkan varietas Bakardi dipanen pada umur 86 hari dan Lolipop pada umur 106 hari. Oleh karena itu didapatkan perbedaan hingga 20 hari antar kedua varietas tersebut. Apabila ingin mendapatkan kualitas yang baik dan umur panen yang serempak maka tidak hanya perlu dilakukan pengaturan lama penyinaran tambahan namun juga adanya pengaturan waktu tanam. Varietas Lolipop yang mempunyai umur lebih lama ditanam 20 hari lebih awal.

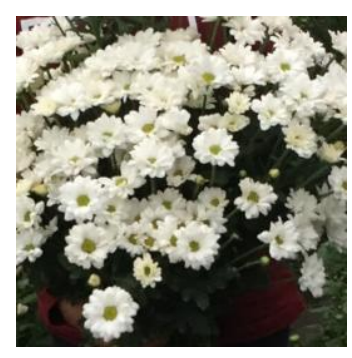

Bakardi Putih

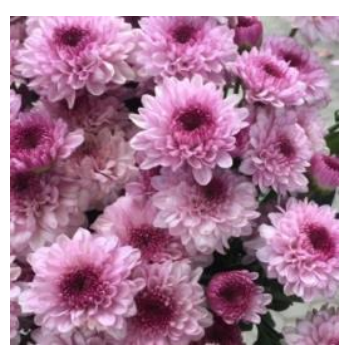

Lolipop Ungu 
Sylvatera Ayu Puspita et al., / Vegetalika. 2018. 7(4): 58-73

\section{KESIMPULAN}

1. Penyinaran tambahan 20 hari pada varietas Bakardi Putih dan 30 hari Lolipop Ungu menghasilkan bunga krisan yang telah memenuhi grade A SNI. Peningkatan lama penyinaran tambahan sampai dengan 40 hari dapat meningkatkan pertumbuhan, hasil dan kualitas varietas Bakardi Putih lebih baik dibandingkan varietas Lolipop Ungu.

2. Penyinaran tambahan 20 hari pada varietas Bakardi Puth dan 30 hari varietas Lolipop Ungu belum dapat menyerempakkan umur panen kedua varietas. Pada penyinaran 20 hari, umur panen varietas Bakardi Putih 86 hari dan 30 hari varietas Lolipop Ungu 106 hari.

\section{SARAN}

1. Perlu penelitian lebih mendalam lagi mengenai pengaruh lama penyinaran tambahan dan jam penambahan penyinaran yang tepat setiap harinya pada varietas Bakardi Putih dan Lolipop Ungu

2. Untuk menyerempakkan umur panen kedua varietas dengan mendapatkan kualitas yang baik pula perlu dilakukan pengaturan waktu tanam yang dikombinasikan dengan lama penyinaran optimum masing-masing varietas

\section{DAFTAR PUSTAKA}

Arista, R. S. 2016. Tanggapan anatomis akar dan pertumbuhan krisan terhadap limbah cair industri batik. Skripsi. Universitas Gadjah Mada : Yogyakarta

Chen X. Y., W. Li, and Q. T. Lu. 2011. The xanthophyll cycle and antioxidative defense system are enhanced in the wheat hybrid subjected to high light stress. Journal Plant Physiol. 168: 1828-1836

Danalotos, N. G. \& S. V. Archontoulis. 2010. Growth and biomass productivity of kenaf (Hibiscus cannabinus L.) under different agricultural inputs and management practices in Central Greece. Industrial Crops and Products 32: 231-240.

Ekanantari. 2014. Outlook Komoditi Krisan. Pusat Data dan Sistem Informasi Pertanian, Jakarta.

Han, S., S. M. Chen, A. P. Song, R. X. Liu, H. Y. Li, J. F. Jiang dan F. D. Chen. 2017. Photosynthetic responses of chrysanthemum morifolium to growth irradiance: morphology, anatomy and chloroplast ultrastructure. Photosynthetica 55:184-192 
Sylvatera Ayu Puspita et al., / Vegetalika. 2018. 7(4): 58-73

Jones, R. B. and M. Hill. 1993. The effect of gramicides on the longevity of cut flower. J. Amer. Soc. HORT. SCI.

Kim, Y. J., H. J. Lee, and K. S. Kim. 2011. Night interruption promotes vegetative growth and flowering of Cymbidium. Sci Hortic 130:887-893

Noviawanti, N. 2014. Periode pembungaan pohon dan aplikasinya dalam tanaman. Skripsi. Fakultas Pertanian IPB

Park, Y. G., S. Muneer, P. Soundararajan, A. Manivnnan, dan B. R. Jeong. 2016. Light quality during night interruption affects morphogenesis and flowering in petunia hybrida, a qualitative long-day plant. Horticulture, Environment and Biotechnology 57: $371-377$

Park, Y. J., Y. J. Kim, dan K. S. Kim. 2013. Vegetative growth and flowering of dianthus, zinnia and pelargonium as affected by night interruption at different timings. Horticulture, Environment and Biotechnology 54: 236-242

Pin, D. D, Y. T. Yang, and C. Y. Gow. 1999. Antioxidant activity of water extract of Harng Jyur (Chrysanthemum morifolium Ramat). LWT-Food Science and Technology 32: 269-277

Pusat Penelitian dan Pengembangan Hortikultura. 2006. Budidaya Krisan Bunga Potong (Prosedur Sistem Produksi). Horticultural Research Cooperation Between Indonesia and the Netherlands. 60 hal.

Ristiana, D. S., R. Hidayat dan Sutini. 2016. Dampak lama penyinaran dan metode night break pada pertumbuhan dan hasil tanaman krisan. Plumula 5: 1-9

Rosmayanti, G. A. Wattimena, S. J. Damanik dan T. M. H. Oliem. 2002. Pengaruh fotoperiodisitas terhadap umur beberapa genitop kentang. Jurnal Agronomi 10:59-62

Runkle, E. S., S. R. Padhye, W. Oh, and K. Getter. 2012. Replacing incandescent lamps with compact fluorescent lamps may delay flowering. Scientia Hort. 143:56-61.

Susanto, L. 2013. Pengaruh formula larutan perendaman dan suhu penyimanan terhadap vase life beberapa bunga potong. Skripsi. Universitas Gadjah Mada. Yogyakarta

Vina. 2016. Pertumbuhan dan pembungaan krisan pada berbagai komposisi media tanam. Skripsi. Universitas Andalas : Padang.

Widiastuti, L., Tohari, dan E. Sulistyaningsih. 2004. Pengaruh intensitas cahaya dan kadar darminosida terhadap iklim mikro dan pertumbuhan dan pembungaan tanaman krisan dalam pot. Jurnal IImu Pertanian 11: 35-42

Walton, L. J., L. V. Kurepin, D. M. Reid, and C. C. Chinnappa. 2006. Stem and Leaf Growth of Alpine Sun and Prairie Shade Ecotypes of Stellaria longipes Under Different Photoperiods: Role of Ethylene. Can. J. Bot. 84:1496-1502 
Sylvatera Ayu Puspita et al., / Vegetalika. 2018. 7(4): 58-73

Warnita, E. Sulistiawati., Muhsanati, Reflin, dan Z. Resti. 2015. Prosiding Seminar Nasional dan Rapat Tahun 2016 Semirata, BKS Barat di Palangkaraya 20-21 Agustus 2016 hal 93-98. Pengaruh Komposisi Media Tanam Terhadap Pertumbuhan Tanaman Hias Amarylis.

Yoginugraha, P. P. I., I. M. A. S. Wijaya, dan I. M. Nada. 2017. Kualitas hasil tanaman krisan pada penambahan cahaya lampu led merah secara siklik. Jurnal Teknik Pertanian $5: 35-44$

Zhu S., Y. Yang, H. Yu, Y. Ying, and G. Zou. 2005. Chemical composition and antimicrobial activity of the essential oils of Chrysanthemum indicum. Journal of Ethnopharmacology $96: 151-158$. 